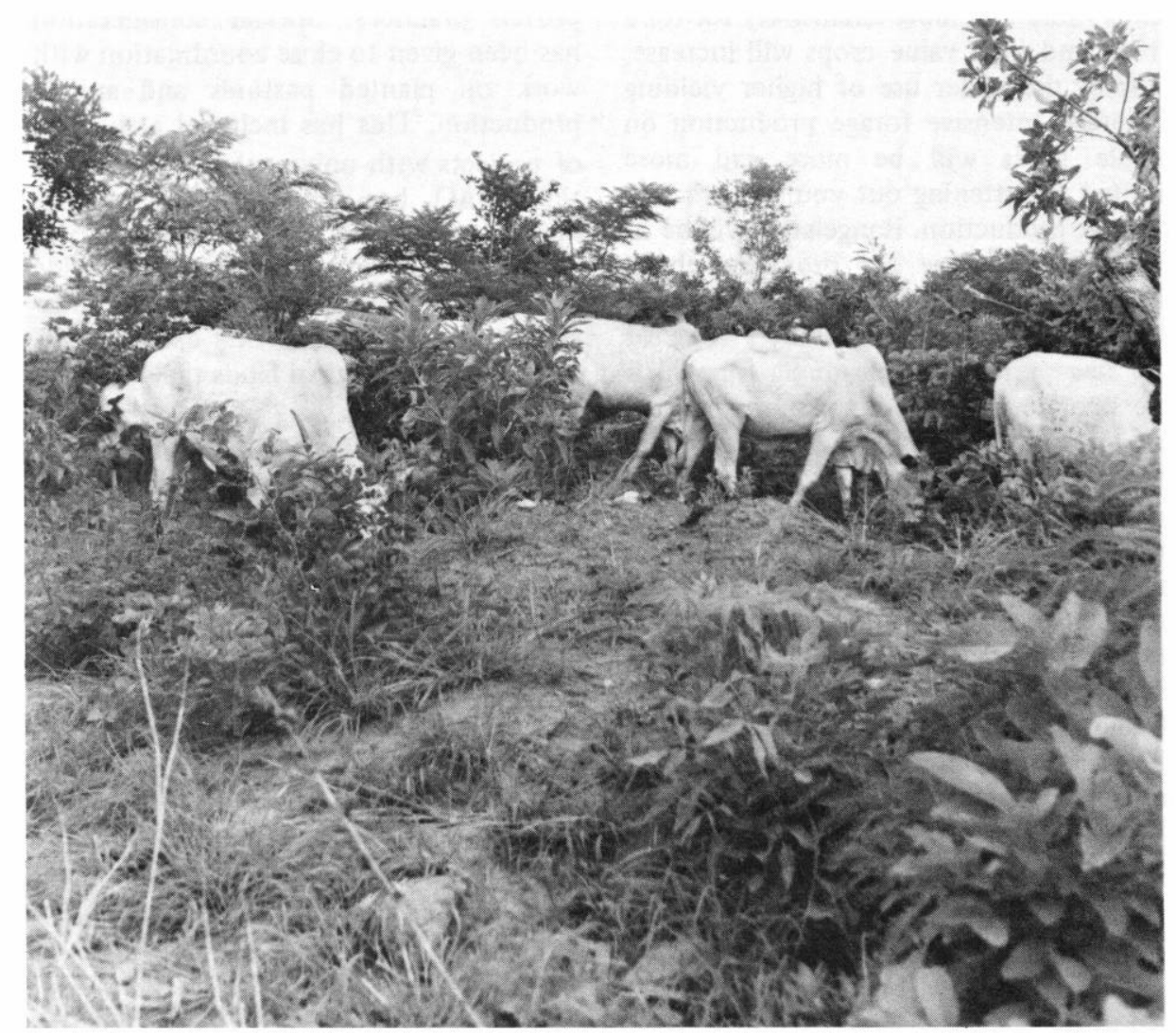

\title{
The Work of FAO in Range Management
}

\section{ROALD A. PETERSON}

Highlight: The central aim of making better use and preventing deterioration of rangelands in developing countries depends primarily upon improving the management of these lands. This in turn calls for vastly increased investments in research and development. Significant progress has been made in creating a wider appreciation of the grazing resource, increasing technical competence, and improving knowledge of the resource. Less progress has been made in developing organizations competent to manage grazing lands. However, experience to date has clearly shown the importance and feasibility of more coordinated and comprehensive approaches to overcome this obstacle. As effective organizations are built, the opportunities and incentives for investment in range research and development should sharply increase.

Almost one-half of the earth's land surface is used for grazing, and the great bulk of animal feed comes from such lands in developing countries. Management levels are generally totally inadequate. If management is to be improved, the current low level of investments in research and development will need to be increased very substantially.

The author is chief, Crop and Grassland Production Service, Plant Production and Protection Division, Food and Agriculture Organization of the United Nations, Rome, Italy.

The paper was presented at the 26th Annual Meeting of the Society for Range Management, Boise, Idaho, February 1973.
The consequences of the neglect of rangelands are too well known to need elaboration. This applies particularly to the arid and semiarid lands (Peterson, 1970). The considerable unexploited potential for rangeland improvement and increased production is also widely appreciated. What needs to be more fully appreciated is that in much of the developing world the growth of the human population is bound to acutely accentuate the pressures on rangeland-both through increased animal numbers and through reduction in the area available for grazing. The tendency to use arable 
lands more and more exclusively for food crops and high value crops will increase, despite the wider use of higher yielding varieties. Intensive forage production on arable lands will be more and more limited to fattening out young stock and to milk production. Rangelands will be of crucial importance for providing cheap feed for breeding stock. The growing demand for livestock products (one of the few agricultural products for which the likelihood of surplus is not a worry) cannot but add to the pressures on the rangelands. This growing demand and the increasing monetary value of livestock, however, also has its positive effect in making more evident the economic importance of rangelands which, in turn, should help governments to see the need for an appropriate policy for research and development. It is within this context that I would like to discuss FAO's work in range management.

\section{FAO's Goals}

In order to help create conditions which would further a more appropriate policy of investment in rangeland research and development, FAO's program over the years has been very largely concerned with:

1) Creating general awareness within each country of the importance and particular role of natural grazing lands and their link with other agricultural production,

2) Furthering technical competence at the national level,

3) Increasing knowledge of the grazing resources and developing approaches for practical transformation of management, taking into account the prevailing ecological, cultural, and economic circumstance, and

4) Assisting member countries in creating organizations able to help bring about the needed modifications in current range practices.

\section{FAO's Activities}

Accordingly, FAO's activities, especially during the last decade, have concentrated on field programs to provide advice and to supplement the efforts of governments to provide practical in-service and advanced training as well as to identify problems and evolve programs adapted to local conditions. Field work has emphasized applied research, survey, and range improvement along with pilot programs to work out practical application of proven practices. Special consideration has been given to close coordination with work on planted pastures and animal production. This has included a number of projects with universities. At the same time FAO has, in collaboration with other institutions and organizations, placed great emphasis on improving yields of crops to meet basic food needs and to reduce the need for further extension of cropping into marginal lands that can best serve for grazing.

FAO field projects, for the most part, are financed by the United Nations Development Program. These are based upon approved requests made by member governments. Approval is frequently preceded by feasibility studies. Financing normally includes cost of foreign specialists, fellowships for national counterparts for study abroad, and the equipment needed to carry out the project effectively. Government contributions may include counterpart staff, land, buildings, animals, and locally produced materials. More recently some cooperative activities with bilateral agencies such as US AID have opened up possibilities for more comprehensive and better coordinated programs and more consistent follow-up.

Assistance in range management has increasingly been provided as a component of integrated projects including specialists in animal production, economics, water development, extension, and other pertinent fields, including sociology, as it has become increasingly clear that solutions must take into account complex interrelated systems.

During the last decade some 35 countries in which range grazing is of major importance have received technical assistance. These include 8 in Latin America, 9 in the Near East, 11 in Africa, and the rest in Southern Europe and Asia, including Mongolia. Individual projects usually run for a period of four or five years. However, countries may request continuation of assistance over a longer period. A number of countries have availed themselves of this opportunity-and it is in these countries that the most evident progress has been made. Some few countries, of which Kenya is an outstanding example, have concentrated both multilateral and bilateral assistance on range management and livestock production with exceptional results. Kenya has also integrated training, research, survey, extension, and development activities into a national range management organization.

At the present time FAO has some 30 field officers working primarily with range management and a similar number working on various facets of pasture production. In addition to on-the-job training, some 72 fellowships for advanced studies in range and pasture have been granted during the last decade. Approximately one-half have been in range management.

In addition to the field program, FAO's activities include the organization of meetings to further intercountry activities and exchange of experience, training courses, and studies designed to lay the basis for the more systematic development of range and livestock resources. The latter has included a survey of livestock production (including range and pasture aspects) in the Near East countries and studies of individual countries (FAO, 1972; Blydenstein, 1971). Range handbooks have been aimed at the problems of particular countries or ecological regions (e.g. Allred, 1968). Other accounts of FAO's work in range management and the problems encountered have been given in a number of publications (Pearse, 1966; Peterson, 1964 and 1968; Blydenstein, 1972; Norris, 1972).

\section{Assessing Accomplishments and Some Future Needs}

In assessing accomplishments to date in terms of the objectives mentioned earlier, one can make the following observations:

\section{1) General Awareness of Rangelands}

General awareness of the importance of rangelands has increased. In virtually all countries a considerable number of people appreciate the significance of the natural grazing lands. However, the critical role of rangelands in livestock production and their vulnerability to degradation is still not sufficiently understood by many countries and funding agencies to lead to the policy changes and action required to cope with the problem. The growing awareness of the environment and creation of the Environment Fund by the United Nations, following the Stockholm Conference in 1972, has helped to focus attention on land (including range) deterioration. Nevertheless, there is a continuing need for broadening understanding of rangelands. In this the Society for Range Management can continue to play an increasingly important role.

In addition to the day-to-day work of creating awareness through projects, meetings, etc., there is need for concerted action on a global scale. This could be furthered by a world-wide meeting on range deterioration. Such a meeting would bring together the best knowledge available on the current situation, identi- 
fy the more critical areas, and make concrete proposals for effective action. FAO would be prepared to organize such a meeting if the necessary financial support could be found.

\section{2) Technical Competence at the National level}

Most countries in which range grazing is important now have a nucleus, however small, of rather well-trained technical people working in research, teaching, or development. This is, I believe, the most significant advance that has been made over the past few years. However, no country has the number of range specialists needed to cope with the multitude of problems they face. Training therefore needs continuous emphasis. This need is widely appreciated by member countries-but available finances limit the rate of progress. This is an area in which the Society for Range Management could play a particularly effective role, as could universities which offer education in range science through fellowships, special courses, and interchange of staff.

It is also essential to increase effectiveness of existing staff, for example through better communication among the technical people in countries with common problems and through cooperative research programs to improve the quality, efficiency, and wider use of research results. In this approach it would be highly desirable to tie in expertise in developed countries-including expertise in grassland modelling-to help orient the research more meaningfully, especially toward management problems. FAO is placing increasing stress on this cooperative approach to research.

\section{3) Improved Knowledge of the Resources}

The emphasis which FAO and some other organizations have placed on resource evaluation has been of fundamental importance in helping to create an orientation of research and development more appropriate to the local ecological, cultural, and economic environment. Both nationwide studies to provide a general assessment and detailed integrated surveys have been carricd out. This work, however, needs more emphasis at both nationwide and field survey level. FAO intends to develop a model based on the study of several nations, which any country could use to assess its grazing resources at the national level. Very considerable experience on different types of integrated surveys is available. Some American universities have already taken a special interest in certain countries and in survey methodology. A cooperative effort in this important work would be welcomed by FAO.

\section{4) Building a Range Management \\ Organization}

The long and difficult struggle that the pioneers of range management in the United States went through in developing organizations reasonably effective for coping with range problems is well known. Age-old, tradition-bound, pastoral systems in most developing countries, poor communications, a shortage of financial and human resources, political instability, lack of centralization of responsibility for rangelands, and other factors inevitably make building an effective range management and research organization even more difficult. It is not surprising, therefore, that hardly more than half a dozen developing countries have made reasonable advances in this direction. This lack of organization not only limits the possibility of a significant impact on management practices, but it also inhibits other subsidiary activities, such as the inclusion of range science in the university curricula, because of the limited opportunities for employment. This is a matter which concerns not only member countries but also international, and probably national, financing agencies, as well as FAO.

Faster progress might come through a more coordinated and comprehensive approach among assistance agencies combining various types and sources of aid toward a continuous goal. The feasibility of such collaboration has been well proved in Kenya, where an FAO/UNDP project has provided survey, research, and extension guidance for the development of a national Range Management Division (FAO, 1971). At the same time the project has given technical support for a World Bank project for ranch development, while US AID has provided a professor for training of Kenya staff. US AID has also helped in the development of the northern part of the country. Additionally, another FAO/UNDP project has been carrying out research and demonstration on feeding to increase animal production and permit earlier removal of young stock from the range. The Dutch Government is providing assistance in grass breeding, and Norwegian Aid is financing a project for the collecting and screening of native forage plants. All these programs add up to a comprehensive whole that is bound to have a highly significant impact on the country's economy.

In this connection it is worth noting that research, survey, training, and other activities are hardly justified unless they are aimed at assisting development. Thus, FAO and UNDP have put great emphasis on linking these types of activities as closely as possible to development problems and to encourage investment follow-up in the application of results. This means that the field experts, and especially the project managers, need to know not only their field of specialization but have a clear understanding of the dynamics of development so that they can direct their work toward weak links in the chain of development.

\section{Conclusion}

The effort to make the most effective use of biological resources for food production, particularly for the production of high quality protein, is the basic long-term problem in agriculture. Range management has a key role in this overall effort-both to increase and to stabilize yields from natural grazing lands. The prevailing awareness of the importance of animal protein and the human cnvironment creates opportunities which did not exist in the past. At the same time the accumulated knowledge and recently developed expertise in emerging nations provide essential building blocks. What is needed is a concerted action by all concerned to build on these circumstances to help emerging countries develop organizations which can carry out well formulated range development policy. This in turn will help open the way to greater investments for research and development or rangelands.

\section{Literature Cited}

Allred, B. W. 1968. Range management training handbook for Saudi Arabia. PL:PFC/4. FAO, Rome.

Blydenstein, John. 1971. Recursos forrajeros de Venezuela. AGP:PFC/19. FAO, Rome. 18 p.

Blydenstein, John. 1972. Devcloping range management in Latin America. J. Range Manage. 25:7-9.

FAO. 1971. Range Management Division of the Ministry of Agriculture, Kenya. Interim Report. AGP:SF/KEN 11. Rome, Italy. 41 p.

FAO, 1972. Near East regional study. Animal husbandry, production and health, fodder production and range management in the Near East and FAO's policies and plans for promoting the Animal Industry. FAO, Rome - Cairo. 312 p.

Norris, J. J. 1972. Future range management: problems and solutions. Int. Silver Anniv. Symp. Proc. Dep. of Range Sci., Texas A and M Univ., 20-21 March 1972, College Station, Texas, p. 38-39.

Pearse, C. K. 1966. Expanding horizons in worldwide range management. J. Range Manage. 19:336-340.

Peterson, R. A. 1964. Improving technical assistance in range management in developing countries. J. Range Manage. 17:306-309.

Peterson, R. A. 1968. Range management activities of the Food and Agriculture Organization of the United Nations. Annals of Arid Zone, 7(2): 150-162.

Peterson, R. A. 1970. Land utilization in non-irrigated areas. In Arid lands in transition. Amer. Ass. for the Advance. of Sci., p. 435-449. 